\title{
Study on the Relationship between Luban Culture and the Chinese Architectural Culture
}

\author{
Jianfeng XUN \\ Shandong Urban Construction Vocational \\ Jinan, China \\ e-mail: xunjianfeng1014@163.com
}

\author{
Yidan NIE \\ Shandong Jianzhu University \\ Jinan, China \\ e-mail:1376914526@qq.comline
}

\author{
Huichao QI \\ Shandong Jianzhu University \\ Jinan, China \\ e-mail: 2284170728@qq.com
}

\author{
Dong YANG \\ Shandong Jianzhu University \\ Jinan, China \\ e-mail: 497128514@qq.com
}

\begin{abstract}
Luban culture is the source of Chinese architectural culture, which leads to the development of Chinese architectural culture. How does Luban culture affects the Chinese architectural culture, and how can we promote urban culture at the present stage, all of these are worth deeply analyze. This paper defined the urban culture connotation. Secondly the relationship between Chinese traditional architecture and urban culture were discussed. And lastly the impact of Luban culture on modern Chinese architecture was also analyzed. Some suggestions were proposed in the paper that urban culture should more be integrated into Chinese architectural culture to improve the connotation of Chinese architectural culture.
\end{abstract}

Keywords-architecture culture; western culture; humanism; respect natural

\section{INTRODUCTION}

Luban started in the late spring and Autumn Warring States at the beginning of the outstanding inventors and craftsmen and construction industry, he invented many useful things. According to legend, he made a siege by the "ladder", a boat used in battle "hook", with the authorities horse, he invented the square, fountain, chisel, plane and other tools, he has been admired by all the craftsmen. But he also used the unique technology built houses, temples, pavilions, bridges and so on; those are important contributions to our social development. After his death, people built temples dedicated to Luban, and Luban is known for the construction industry "Ancestors". Have a profound impact on the modern architectural culture, and guided the construction and development of modern architectural culture [1].

\section{The CONNOTATION OF LUBAN CULTURE}

Luban's historical records are not systematic, only sporadic records, but also can be seen from these records Luban is an excellent craftsman which involves a wide range of industries. In addition, the spirit of Luban mainly came from the legend of Luban, the legend of Luban came from reality and it was rich in historical development.
According to historical records came from different content and scope of the Han Dynasty, the legend of Luban's ancient records are divided into two stages, including before the Qin Dynasty the and the Han Dynasty .They said Luban has a "smart" description, and basically concentrated in the woodworking industry. From the Han Dynasty, Luban legend had become rich and more developed, Luban was known not only on the field of carpentry but also in other areas that he had also contributed different ideas Especially in modern times, Luban is not only a coincidence it was planned and executed properly. Luban culture is for modern construction industry respect learning.

\section{A. Diligence and Good Learning}

Hard work is the fine tradition of the Chinese nation; this tradition has been well reflected in the legend of Luban. Luban is a legend of an ordinary person's id, his skills were the result of his dedication to work and his talents were not an inborn thing but it was developed by pure training and perseverance. Luban was very studious during his school days, the young Luban to ZhongNaShan Baishixueyi, made great efforts to finally meet the master, master of withstand test for him, in three years of study, Luban had a hard time on China's building development lesson.

\section{B. Pay Attention and Practice}

The combination of knowledge and practical experience is a valuable asset to a professional life, as it makes you a skilled person to carry out your task successfully. Both knowledge and experience are closely related to each other. In the sense, without knowledge you may not gain practical experience and in the absence of practical experience, your knowledge and concepts cannot be strengthened. Also experience must be considered as a part of knowledge that comes through experiments or doing things practically. It is therefore important to gain both knowledge and experience, so that you can lead a good professional life while you may find many ways for professional development.

Luban went to the city of Suzhou, a millionaire built the pagoda, so Luban decided to help the artisans Fuzheng 
pagoda. He let people find some wood, and then cut into many small wood inclined wedge, a piece of land from the top side of tilt to knock, inclined side slowly raise, the results came after one month, the pagoda was standing upright. Such legends have close ties with the craftsmen's practical experience, if he doesn't have an experience I think chances are he will not be able to finish that work and it is impossible for him to deal with problems in a timely manner and this important for the legend of Luban in the construction industry, because this is not just to remind the staff to strengthen the construction industry practice, which contains certain scientific factor it can also provide an inspiration for building modern design.

\section{Good at Innovation}

Innovation is a source of continuous progress in a country and an industry Innovation may be defined as exploiting new ideas leading to the creation of a new product, process or service. It is not just the invention of a new idea that is important, but it is actually "bringing it to market", putting into practice and exploiting it in a manner that leads to new products, services or systems that add value or improve quality. It possibly involves technological transformation and management restructuring. Innovation also means exploiting new technology and employing out-ofthe-box thinking to generate new value and to bring about significant changes in society. Luban was good at innovation; he invented the plane, the invention of the graphite, the invention of the fountain. According to legend, Luban once saw an old lady in the pound of wheat, he held the stone pestle mortar in research of wheat. So he was inspired to go home and polished two discs, he installed the wood in the middle of the shaft connected to the disc he had Put the wheat in the circular hole in the middle of the rotating disc, and then turned wheat into flour. That's what we're still using until now.

Luban was good in discovering and thinking, he created new ideas for other people.

The spirit of innovation can promote the development of the industry, especially the construction industry as a pillar industry in China, but also we need to innovate in order to promote the development of other industries and promote economic progress.

\section{Sense of Responsibility}

Sense of responsibility is a very important quality. A carpenter must do his work well. One upon a time he gave the emperor a chance to repair his palace in a short given time he has done and finished the task even if it was a very heavy responsibility, He was very anxious on that time, their axes were not long enough and not that thick to cut wood so he taught a fellow carpenter that they should know the material first and they should be responsible for outcome and result of a specific work, they can not be careless. The product of the construction industry, whether it is residential buildings, office buildings or art buildings, is closely related to human life in the city. The quality of construction is related to the quality and safety of human life. So only a strong sense of responsibility engineers, to create a rigorous product can promote the development of the industry.

\section{E. Unity and Cooperation}

Unity and cooperation is not only a superposition of personal strength but can be sublimated. In the spread of Zhenjiang about Luban and Zhang Bantian legend: Sun Wukong broke the sky. The emperor let Luban and Zhang ban to repair the sky. Zhang Ban is a bricklayer, Luban is a carpenter, to make up the sky, and Zhang Ban in the above make up, Luban in the following repair, and then the sky has been fixed [3].

This legend of unity and cooperation reflects the Luban as an ordinary craftsman, although with outstanding wisdom, but still need to integrate into the collective, to make a greater cause. So that each project is need different people cooperation to complete and all the positions of the people together in order to ensure the smooth progress of the project.

Luban as a "founder" of the construction industry, his fine qualities and his spirit set up a monument in thousands of years of Chinese culture, and become a distinctive banner of China architectural culture in the inheritance and development of several thousand years.

\section{THE ORIGIN OF CHINESE TRADITIONAL ARCHITECTURE AND LUBAN CULTURE}

The traditional architecture of China is about the "harmony between man and nature", that is, the relationship between things and people and things is harmonious. Man and nature as a whole, people can not control the nature. People need to respect the nature. So Chinese traditional architecture combined with nature, human beings tend to build houses in the original environment and do as much as possible not to undermine the original natural environment. Chinese people pay attention to feng shui, that is the case, reflected as "Surrounded by mountains and girdled by a river" and "The winding path leads to a secluded quiet place" [4] Chinese traditional architecture also pay attention to the "ren, he, zhong, an", the building of the Imperial Palace which is fully reflected. Described above are luban spiritual message of "righteousness".

According to historical records, Luban and Mozi talked about in the view of righteousness. Luban said to Mozi: "If I accept the song kingdom. I violate the righteousness, I would rather have nothing." Mozi said, "If you do your best in every place, I will give you the whole world."In this dialogue, we can see Luban's deep understanding of righteousness and the persistence of righteousness. By the influence of Mozi, Luban heart of righteousness more strong, he found the cruelty of war and then gradually put their talents from the military to the building.

Chinese architecture has become rich and colorful under the influence of the Chinese nation's the concept of righteousness of all-inclusive and the spirit of all rivers run into sea. Especially since the Luban, in the subsequent formation and inheritance of the spirit of Luban, the architectural skills of the transfer of human feelings have become more and more strong. China traditional building both magnificent palaces and simple houses reflect Luban's 
benevolence and all of these shining humanity. Chinese traditional architecture of the structure, function and bearing the concept of benevolence constitute the blood of Chinese architectural culture.

\section{THE INFLUENCE OF LUBAN CULTURE ON MODERN ARCHITECTURE IN CHINA}

\section{A. The Present Situation of Chinese Modern Architecture}

After the Han dynasty, science and technology was regarded as an indecent thing, so that generations of intellectuals were buried in the sages and seldom studied science and technology. Therefore, since the Ming and Qing dynasties, China's architectural culture from prosperity to decline, so that with the infiltration of Western culture, the Chinese civilization exhausted and appear a serious cultural crisis. After the reform and opening up, China gradually into the world, and the pace is getting faster. After the reform and opening up, China's gradual integration into the world, and the pace is faster and faster. Under the condition of rapid economic development of reform and opening-up, China's construction industry ushered in a picture of another village. The construction industry vigorous development, at the same time promoting the speed of China's industrialization and the rise of national economic. All over the country to carry out the process of urbanization and update the construction of a large group, which provides an active market for our architects. However, both opportunities and challenges, the current Western architectural theory into China, especially now a large number of Western architectural talent in the Chinese construction market. This situation has a dramatic impact on the heritage of traditional Chinese architectural culture and curbs the development of China's modern architecture, so that the construction industries in China facing a huge challenge [5].

Influenced by the western architecture, many cities appear to imitate western architecture. For example, Zhengzhou appeared France Ronchamp, Hangzhou has also appeared in Hangzhou version of "Hangzhou tower", Suzhou have appeared in the Suzhou version of the "London's tower bridge" and so on. With the gradual improvement of technology, new materials, cement reinforced by a wide range of sources, housing is more robust and durable and compared to the previous wood based housing is also easier to build. The use of modern machinery is also convenient for building houses, more and more get the favour of people, so the city appeared the phenomenon of building monotony .In addition, the rapid development of modern economy, people are more concerned about the interests rather than the culture, so a variety of "bean curd residue" projects are not uncommon. All these phenomena show that the loss of Chinese traditional architectural culture, so more attention should be attached to the Luban culture [6].

\section{B. The value of Luban Culture}

Facing the current situation of construction in China, we should base on the existing problems in China's construction industry, and then transform the Luban culture and promote the Luban spirit in the whole society, in order to effectively solve the severe challenges.

Innovation is the soul of the spirit of Luban. In the history of Chinese culture for thousands of years, the building as a carrier of culture has also been changing. Each generation toward the building has its own characteristics, discard the dross and select the essence, and then continue to grow. Up to now, whether for construction workers or construction-related enterprises, innovation is still the driving force for the promotion of work and enterprise development. Especially in the new century, social development emphasizes efficiency, for enterprises, innovative technology and materials can improve the core competitiveness of enterprises. The spirit of Luban heritage is conducive to the continuation of the spirit of innovation of science and technology of China since ancient times, so that China's scientific and technological innovation rooted in the profound national cultural soil and robust development [7-8].

In order to promote the improvement of construction quality in China, the ministry of construction to create "construction Luban prize". The Luban Prize means that this project integrates innovation, excellence and humanistic feelings, and integrates the Luban culture and engineering practice effectively. With the "Luban Award" has gradually been taken seriously, many companies are competing to improve the quality of projects for Luban awards. For example, Shanghai Construction Engineering Group four companies around the creation of Luban Award, for twenty consecutive years to carry out the "grasp quality, strict management, and brand construction" theme activities. The whole group formed a good atmosphere of building brand projects, creating brand project department and to be a brand employee.

Nowadays, the eastern and western cultures are increasingly blending [9-10]. We should be based on present situation and future development of Chinese modern architecture and then find the right direction, heritage and innovation of traditional Chinese architectural culture. An important measure to promote the inheritance and innovation of Chinese traditional culture is to promote the culture of Luban. In dealing with the issue of traditional Chinese culture, the first is how to inherit and creative development of traditional culture. Luban culture has a long history and a wide range of influence. It is one of the important branches of the outstanding traditional culture of our country. Luban culture has played an important role in the promotion of the formation of the Chinese national spirit, national temperament, national character, national customs and habits.

At present, China increases the mining strength of the spirit of Luban, combing the context and finding out the part that is beneficial to the development of modern architectural culture in our country. This makes the spirit of Luban flourish in our country, enhance our cultural self-confidence and self-consciousness and become the strong one on a robust tree. 


\section{CONCLUSION}

Luban culture is rich in cultural content, including practice, innovation, responsibility, collaboration and so on. Luban culture is the source and important part of Chinese architectural culture, have a profound impact on Chinese architectural culture. The Luban culture also plays an important role in promoting the formation of the national spirit, national temperament, national character and national customs of the Chinese nation. However, with the exchange and collision of western culture, the traditional Chinese architectural culture has been weakened by the influence of western architecture and the urban architecture is monotonous that it presents the phenomenon of cement forest. The solution of these problems needs to pay attention to the development of Luban culture, promote the culture of Luban, so that Luban culture can lead the development of traditional Chinese architecture. Then Luban culture should be integrated into the construction of Chinese architectural culture and enhance the connotation and the international influence of China's traditional culture, which can lead the healthy development of China's construction culture.

\section{ACKNOWLEDGMENT}

This work was financially supported by the Luban Seminar Foundation of Shandong Jianzhu University which is hosted by Prof. Yang.

\section{REFERENCES}

[1] Tan Wuzhou. The Study of Luban's Belief [D]. Wuhan: South-central University for Nationalities, 2010.

[2] Tian Hua. The Study of Luban Legends [D]. Xiangtan: Xiangtan University, 2003.

[3] Fang Guangyu. Selection of Dai Folk Stories [M]. Shanghai: Shanghai literature and Art Publishing House, 1985.

[4] Heyu. The Inheritance and Application of Huizhou Architectural Culture in Modern Interior Design [D]. Changsha: Hunan Normal University, 2014.

[5] Xu Gongfang, Li Qiang, Denhwenhua. Promote Luban Spirit and Cultivate High-Quality Constructive Talents [J]. Higher Education, 2010, 6:98-103.

[6] Jiang Hao. An Analysis of Luban's Culture of Architecture [J]. The Border Economy and Culture, 2012, 7:27-28.

[7] Zhao Rentong. The Spirit of Luban: the Blood of Chinese Architectural Culture [N]. Construction Times, 2006, 007.

[8] Sun Zhongyuan. The Significance of Luban's Cultural Studies-From Complete library in the Four Branches of Literature [J]. Journal of Wuhan University of Science and Technology, 2011, (1).15-18.

[9] Almeida N, Sousa V, Dias L A, et al. A framework for combining risk-management and performance-based building approaches [J]. Batiment International, Building Research and Practice, 2010, 38(2):157-174.

[10] Soriano D R. New Information and Communication Technologies for Knowledge Management in Organizations [M]. New Information and Communication Technologies for Knowledge Management in Organizations: 5th Global Innovation and Knowledge Academy Conference, GIKA. Springer Publishing Company, Incorporated, 2015. 